E3S Web of Conferences 1, 17002 (2013)

DOI: $10.1051 / \mathrm{e} 3$ sconf/20130117002

(c) Owned by the authors, published by EDP Sciences, 2013

\title{
Trend and seasonal variation of atmospheric mercury concentrations at the Cape Point GAW observatory, South Africa
}

\author{
E.-G. Brunke ${ }^{1}$, R. Ebinghaus ${ }^{2}$, H. H. Kock ${ }^{2}$, A. Weigelt ${ }^{2}$, C. Labuschagne ${ }^{1}$ and F. Slemr $^{3}$ \\ ${ }^{1}$ South African Weather Service c/o CSIR, P.O. Box 320, Stellenbosch 7599, SOUTH AFRICA, \\ ernst.brunke@weathersa.co.za \\ ${ }^{2}$ Helmholtz-Zentrum Geesthacht, Institute of Coastal Research, Max-Planck-Strasse, D-21502 Geesthacht, GERMANY, \\ ralf.ebinghaus@hzg.de,hans.kock@hzg.de, andreas.weigelt@hzg.de \\ ${ }^{3}$ Max-Planck-Institut für Chemie, P.O.Box 3060, D-55020 Mainz, GERMANY,franz.slemr@mpic.de
}

\begin{abstract}
Gaseous elemental mercury (GEM) has been measured at the WMO Global Atmospheric Watch station at Cape Point, South Africa since September 1995. Two techniques were used: a low resolution manual technique till the end of 2004 and a high resolution automated technique since March 2007. The GEM measurements at Cape Point constitute only one component of the GAW monitoring program consisting of continuous measurements of $\mathrm{CO}, \mathrm{CH}_{4}, \mathrm{CO}_{2}, \mathrm{O}_{3}, \mathrm{~N}_{2} \mathrm{O}$, and since March 1999 also of ${ }^{222} \mathrm{Rn}$. The seasonality and trend of GEM concentrations from the low resolution data was analyzed by Slemr et al. (2008) and the trend of the combined low and high resolution data until the end of 2009 by Slemr et al. (2011). In this paper we will present an updated analysis of the trend and seasonality of GEM data until the end of 2011 and compare these to measurements made at Troll, a Norwegian research station in Antarctica (Pfaffhuber et al., 2012).
\end{abstract}

Key words: Heavy metals, mercury, emission, deposition, flux, terrestrial surface

\section{Introduction}

Measurements of gaseous elemental mercury (GEM) made at Cape Point, South Africa, since September 1995 represent the longest existing time series of GEM measurements and, to the best of our knowledge, the only one exceeding 5 years in the southern hemisphere. Two techniques were used: a low resolution manual technique until the end of 2004 (Slemr et al., 2008) and a high resolution automated technique since March 2007 (Slemr et al., 2011). An analysis of the low resolution data (about 150 measurements per year, each covering $3 \mathrm{~h}$ sampling time) by Slemr et al. (2008) revealed a substantial decreasing trend and a seasonal variation with maximum GEM concentrations in austral summer. Slemr et al. (2011) analyzed the combined low and high resolution data until the end of 2009 and found: a) no evidence of a data discontinuity due to the change in techniques, b) an agreement with ship measurements made in the vicinity of Cape Point and c) a pronounced decreasing trend amounting to $-0.034 \pm 0.005 \mathrm{ng} \mathrm{m}^{-3} \mathrm{yr}^{-1}$.

In the meantime the high resolution data revealed the existence of hitherto unexplained short depletion events (Brunke et al., 2010). Analysis of pollution events provided an estimate of GEM emissions in southern
Africa which is in reasonable agreement with recent bottom-up emission inventories (Brunke et al., in print) and an analysis of ${ }^{222} \mathrm{Rn}$ events suggesting that the terrestrial surface of southern Africa is a larger net sink of atmospheric mercury than presumed by a current global atmospheric mercury model (Slemr et al., this conference). In this paper we will present a trend analysis of the data set extending till the end of 2011 and a re-analysis of seasonal variation from the high resolution data.

\section{Materials and Methods}

The Cape Point station is part of the World Meteorological Organization's (WMO) Global Atmosphere Watch (GAW) network. It is located about $60 \mathrm{~km}$ south of Cape Town on top of a coastal cliff 230 $\mathrm{m}$ above sea level at the southern-most tip of the Cape Peninsula. The dominant wind direction is from the south-eastern sector which is representative of clean maritime air. Occasionally, the site is also subjected to air from the northern to north-eastern sector which is influenced by anthropogenic emissions from the greater Cape Town area and by other continental sources.

Between September 1995 and December 2004 
mercury was collected on cartridges packed with Au or Ag coated quartz wool which were then analysed manually in a laboratory (Slemr et al., 1985). Since March 2007 a Tekran 2537A analyser has been operated at Cape Point for the measurement of mercury. Under the prevailing conditions of higher temperature, humid air and sea salt aerosols we assume that reactive gaseous mercury (RGM) will not pass through the inlet tubing. Consequently, we believe that only GEM is being measured.

\section{Results and Discussion}

Fig. 1 shows an updated time series of GEM median concentrations of all measurements at Cape Point since September 1995 until the end of 2011. Annual medians and averages from the "all data set" were found to be statistically the same as the annual medians and averages for the baseline data (defined as GEM concentrations at ${ }^{222} \mathrm{Rn} \leq 250 \mathrm{mBq} \mathrm{m}^{-3}$ (Brunke et al., 2004; Whittlestone et al., 2009)). All measurements were thus used in Fig. 1, because ${ }^{222} \mathrm{Rn}$ measurements are available only since March 1999 and the application of the baseline filter on the other low resolution data would reduce the data base to merely 30 measurements per year. Over the whole period the GEM concentrations decreased with a significant trend of $-0.028 \mathrm{ng} \mathrm{m}^{-3} \mathrm{yr}^{-1}$ (Sen's slope estimate, significant at the $99.94 \%$ level). However, no systematic trend is visible in the high resolution data since March 2007. Using monthly medians for the "all data" and baseline measurements, no significant trends are detectable by the Mann-Kendall test in the high-resolution data. This is in agreement with the absence of a significant trend at Troll, a Norwegian research station in Antarctica, for a somewhat shorter period (February 2007 till the end of 2010) which has recently been reported by Pfaffhuber et al. (2012). In contrast to the absence of trends at both stations in the southern hemisphere, a decreasing trend of $-0.049 \mathrm{ng} \mathrm{m}^{-3}$ $\mathrm{yr}^{-1}$ can be derived from the GEM monthly means at Mace Head since March 2007 until the end of 2011.

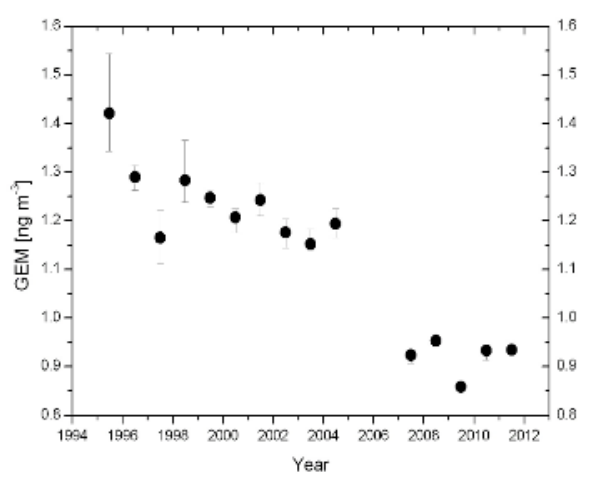

Fig. 1. Cape Point annual median GEM concentrations (all data) with standard median errors.

Pfaffhuber et al. (2012) report an average mercury concentration of $0.93 \pm 0.19 \mathrm{ng} \mathrm{m}^{-3}$ and a median of 0.97 $\mathrm{ng} \mathrm{m}^{-3}$ for the period from February 2007 until the end of 2010 for the Troll station. This is in excellent agreement with the average GEM mercury concentration of $0.92 \pm$ $0.10 \mathrm{ng} \mathrm{m}^{-3}$ and the median of $0.92 \mathrm{ng} \mathrm{m}^{-3}$ observed at Cape Point and averaged over almost the identical time interval from March 2007 to the end 2010. This agreement suggests that the latitudinal gradient postulated by Slemr et al. (2009) did not exist during this period. However, latitudinal gradients may, indeed, have existed during the period with a substantial downward trend before 2007 .

The seasonal variation of GEM concentrations is shown in Fig. 2. Apart from higher GEM concentrations in July and August, the seasonal variation shows a maximum during February, March and April and a minimum in September. Hereby it resembles the seasonal variation derived by Slemr et al. (2008) from the low resolution data which showed a maximum in January and February and a minimum in July to September. The maxima in July and August in the high resolution data look like a systematic feature whose origin has yet to be investigated.

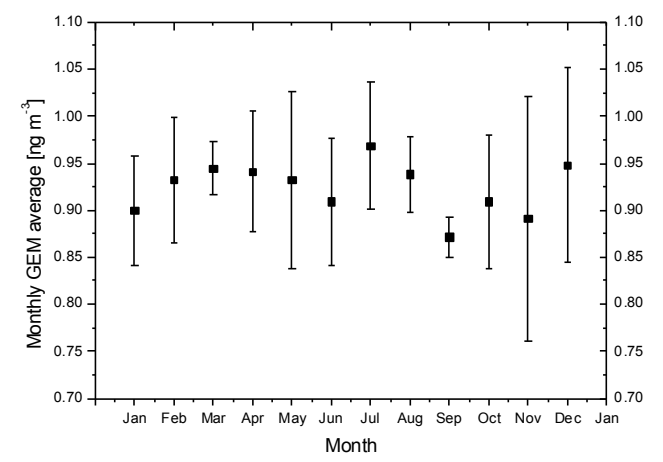

Fig. 2. Seasonal variation of baseline GEM concentrations (baseline defined as GEM concentrations at ${ }^{222} \mathrm{Rn} \leq 250 \mathrm{mBq} \mathrm{m}^{-3}$ ) at Cape Point since March 2007 until the end of 2011 .

The seasonal variation at the Troll station (Pfaffhuber et al., 2012) is different with a maximum from April till July and a minimum in austral spring and summer (November - January). The difference is most likely due to mercury depletion events in Antarctica occurring during austral spring and summer (Steffen et al., 2008).

\section{Conclusion}

A decreasing trend of GEM concentrations amounting to $-0.028 \mathrm{ng} \mathrm{m}^{-3} \mathrm{yr}^{-1}$ was observed at Cape Point since 1996 until the end of 2011. However, no trend could be detected in the high resolution data since March 2007 which on average remain constant at $0.92 \pm 0.10 \mathrm{ng} \mathrm{m}^{-3}$ (median of $0.92 \mathrm{ng} \mathrm{m}^{-3}$ ). The absence of a GEM trend is in agreement with the observations at Troll, a Norwegian research station in Antarctica. The average GEM concentrations at the Cape Point and Troll stations are in excellent agreement suggesting the absence of a significant latitudinal gradient in the years 2007-2010. The seasonal variations of GEM concentrations at both 
stations are different. The most probable reason is the occurrence of polar mercury depletion events encountered at the Troll station in austral spring and summer.

\section{Acknowledgements}

The authors thank for the financial support received from the European Commission within the GMOS (Global Mercury Observation System, www.gmos.eu) project (FP7-ENV-2010).

\section{References}

Brunke, E.-G., Labuschagne, C., Parker, B., Scheel, H.E., Whittlestone, S. Baseline air mass selection at Cape Point, South Africa: application of ${ }^{222} \mathrm{Rn}$ and other filter criteria, Atmos. Environ. 38, 5693-5702, 2004.

Brunke, E.-G., Labuschagne, C., Ebinghaus, R., Kock, H.H., Slemr, F. Gaseous elemental mercury depletion events observed at Cape Point during 2007 and 2008, Atmos. Chem. Phys. 10, 1121-1131, 2010.

Brunke, E.-G., Ebinghaus, R., Kock, H.H., Labuschagne, C., Slemr, F. Emissions of mercury in southern Africa derived from long-term observations at Cape Point, South Africa, Atmos. Chem. Phys. Discuss., in print.

Pfaffhuber, K.A., Berg, T., Hirdman, D., Stohl, A. Atmospheric mercury observations from Antarctica: seasonal variation and source and sink region calculations, Atmos. Chem. Phys. 12, 3241-3251, 2012.
Slemr, F., Schuster, G., Seiler, W. Distribution, speciation and budget of atmospheric mercury, J. Atmos. Chem. 3, 407-434, 1985.

Slemr, F., Brunke, E.-G., Labuschagne, C., Ebinghaus, R. Total gaseous mercury concentrations at Cape Point GAW station and their seasonality, Geophys. Res. Lett. 35, L11807, doi:10.1029/2008GL033741, 2008.

Slemr, F., Brunke, E.-G., Ebinghaus, R., Kuss, J. Worldwide trend of atmospheric mercury since 1995, Atmos. Chem. Phys. 11, 4779-4787, 2011.

Slemr, F., Brunke, E.-G., Whittlestone, S., Zahorowski, W., Ebinghaus, R., Kock, H.H., Labuschagne, C. 222Rn calibrated mercury fluxes from terrestrial surfaces of southern Africa derived from observations at Cape Point, South Africa, this conference.

Steffen, A., Douglas, T., Amyot, M., Aspmo, K., Berg, T., Bottenheim, J., Brooks, S., Cobbett, F., Dastoor, A., Dommergue, A., Ebinghaus, R., Ferrari, C., Gardfeldt, K., Goodsite, M.E., Lean, D., Poulain, A.J., Scherz, C., Skov, H., Sommar, J., Temme, C. A synthesis of atmospheric mercury depletion event chemistry in the atmosphere and snow, Atmos. Chem. Phys. 8, 1445-1482, 2008.

Whittlestone, S., Kowalczyk, E., Brunke, E.-G., Labuschagne, C. Source regions for $\mathrm{CO}_{2}$ at Cape Point assessed by modeling, ${ }^{222} \mathrm{Rn}$ and meteorological data, South African Weather Service, Pretoria, South Africa, 2009. 